\title{
The financial behavior of the banking services' consumers regarding the credit- contracting for the crisis-period in Romania
}

\author{
Laura Olteanu, Universitatea Babes-Bolyai, Cluj-Napoca, Romania \\ Izabella Krajnik, Universitatea Babes-Bolyai, Cluj-Napoca, Romania
}

\begin{abstract}
The knowledge of costumer behavior can be interpreted as a provocation in the current economical conditions, however in conditions of crisis it becomes of vital importance. Consumer behavior is influenced by a series of factors. In the present conditions of economic-crisis, the consumers' financial behavior regarding the banking services is strongly influenced by the economic environment. The psychological factor makes itself known, and consumers become more attentive with their financial resources, those owned or attracted.
\end{abstract}

\section{Keywords}

credits, overdue debts, credits in RON and currency, tendency, crisis-periods, influential factors, cash

\section{JEL Codes: M 31}

In an economic market the banking system fulfills the functions to attract and that of the concentration of the society's economies and its channelization, through an objective and impartial processing of allocation of credits, towards the most efficient investments available.

In the fulfillment of these functions, the banks, by providing the basic links of the system, pursue the methods in which the debtors manage their credited resources. Banks assure and facilitate the effectuation of those payments, offer their risk-management services and represent the main channel of transmission in the implementation of monetary policies. By means of the acquisition of financial resources, simultaneously with their placement on the market by means of credits, the operations' discount and that of other opportunities on the financial market, banks play the role of intermediate agents between stockholders and its users. By prosecuting this diversity of operations, banks operate in their name, on their own, the debtors and creditors having none of those related rights among them. Banks manage deposits and the resources of payment from the economy; collecting deposits, banks have the responsibility of their efficient management with a maximum of efficaciousness, in their own benefit and that of the depositors.

In present, banks offer a wide range of financial services. Banking activities are based on two main aspects, that of attracting resources from the exterior/outside or on the other hand, offering financial resources. The price that the bank is paying to attract resources must be less than the price of the financial resources on-offer. In this sense the rate of interest for the filing of deposits gets lower than the rate of interest levied by the bank for the credits.

The financial behavior of the banking services' consumers regarding the credits' contracted for the crisis-period in Romania, offers an image of the dynamics of credits in RON and other currencies contracted by the population, but also by the economic agents in the period of 2007-2009. Moreover it accentuates the modifications, which occurred in regards of current credits and back interests, and also for those types of credit that were contracted by 
individuals and legal entities. The final conclusions obtained from the analysis are the results of a desk research.

Credits are negotiable banking instruments. ${ }^{1}$ Banks lend for their clients sums of money for the financing of their businesses. ${ }^{2}$

Banks offer credits for individuals, but also for legal entities. Credits offered for individuals can have a great variety of application. To procure a loan, the solicitant has to file an application for credit. The creditor, according to the interests and possibilities, can reject the application for credit or gets on with the evaluation of the potential client.

The main provisions regarding the specifics of a credit's contract are: destination of the credit, the volume of the credit, the period of lending, the form of credit, rates and costs, the coverage for resources, time limits, indemnification, other elements (provisions). All of the above mentioned elements are enclosed within a contract. For individuals, banks offer credits for diverse applications:

- Credits for vacation

- Land purchase

- Real estate purchase, vacation homes

- Purchase of durable goods

- Auto vehicle purchase

- Other destinations

Credits can be lent in RON and other currencies. Banks lend credits due to the fact that these represent the main source of income. In this sense banks are interested in offering credits, but have to take a strict evidence of their baleful clients.

Table no. 1 The evolution of current credits and overdue debts in RON for the period of 2007-2009

\begin{tabular}{|l|r|r|r|}
\hline \multicolumn{1}{|c|}{ RON } & \multicolumn{1}{c|}{ Dec 2007 } & \multicolumn{1}{c|}{ Dec 2008 } & \multicolumn{1}{c|}{ Dec 2009 } \\
\hline Credits RON & $\mathbf{6 7 8 0 0 ~ 1 9 8 ~ 4 3 4 , 7 7}$ & $\mathbf{8 3 ~ 7 4 6 ~ 1 4 2 ~ 9 1 4 , 4 9}$ & $\mathbf{7 9 ~ 7 8 7 ~ 5 3 9 ~ 9 9 8 , 2 7}$ \\
\hline current & 67038054772,55 & 81934048636,53 & 75444725505,52 \\
\hline overdue debts & 762143665,36 & 1812094278,14 & 4342814491,41 \\
\hline
\end{tabular}

Source - www.bnr.ro

Credits in RON registered an increase for the analyzed period, from 67800198434,77 RON in 2007 to 79787539 998, $27 \mathrm{RON}$ in 2009, representing an increase of 17,68\% in 2009 in regard to 2007. Within the precincts of credits in RON it can be observed that although current credits/loans have registered an increase for the entire period, as a ponderosity in total of credits in RON calculated for each year registered a decrease of those in company with default credits of which ponderosity has registered meaningful increases. Thereby overdue debts registered in 2007 a ponderosity of $1,12 \%$ of total of credits in RON, in 2008 this ponderosity has increased to $2,16 \%$, as in 2009 to $5,44 \%$.

\footnotetext{
${ }^{1}$ Dardac Nicolae, Basno Cezar, Operaţiuni bancare. Operațiuni şi tehnici de plată, 1996, Editura Didactică şi pedagogică, Bucureşti, pg. 140

2 Ionescu Lucian (coordonator), Fundamentele profesiunii bancare. Băncile şi operațiunile bancare, 1996, Ed. Economică, Bucureşti, pg. 210
} 


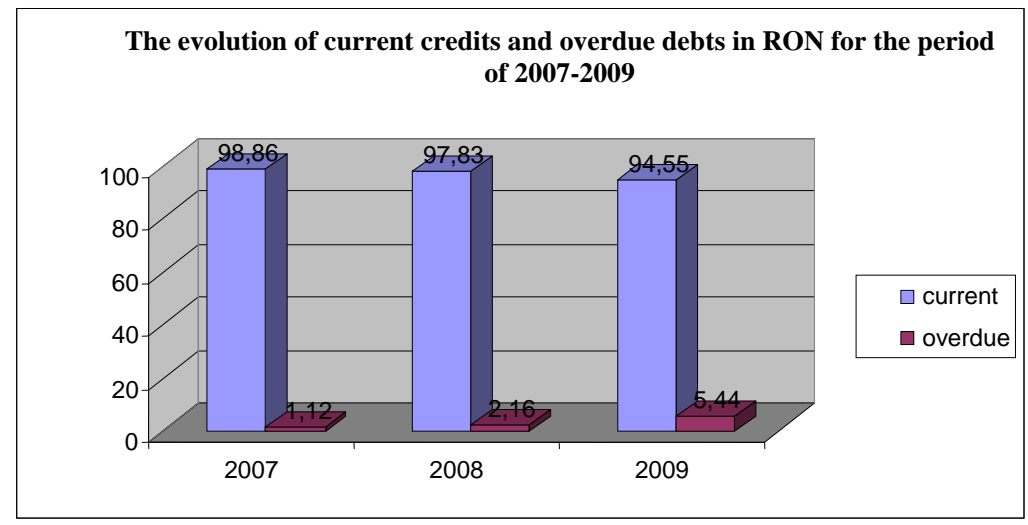

Graphic no. 1

Source - www.bnr.ro

It can be found that at the end of year 2008, the value of contracted credits has been bigger than at the end of year 2009, but concerning the analyzed period, increases can be highlighted for all analyzed categories of credits. Regarding the ponderosity of credits lent for every year in part, on total value of credits, individuals have moderated their upsurge to credit contracts. As in 2007 individual consumers held 49,52 \% from the total of loans credited, in 2009 the value of those was reduced to $48,65 \%$. For the analyzed period, the value of credits contracted by individuals registered an increase of $15,61 \%$, and the value of contracted credits by legal entities registered an increase of $20,35 \%$.

Table no. 2 The evolution of credits lent in RON for the period of 2007-2009

\begin{tabular}{|l|r|r|r|}
\hline \multicolumn{1}{|c|}{ RON } & \multicolumn{1}{c|}{ Dec 2007 } & \multicolumn{1}{c|}{ Dec 2008 } & \multicolumn{1}{c|}{ Dec 2009 } \\
\hline Credits in RON & $\mathbf{6 7 8 0 0 ~ 1 9 8 ~ 4 3 4 , 7 7}$ & $\mathbf{8 3 ~ 7 4 6 ~ 1 4 2 ~ 9 1 4 , 4 9}$ & $\mathbf{7 9 ~ 7 8 7 ~ 5 3 9 ~ 9 9 8 , 2 7}$ \\
\hline economic agents & 32597434201,35 & 40967023648,72 & 39232528620,79 \\
\hline population, of which: & $\mathbf{3 3 5 7 3 6 5 7 4 5 9 , 4 5}$ & $\mathbf{4 0 ~ 9 4 0 ~ 1 0 5 ~ 7 1 2 , 0 3}$ & $\mathbf{3 8 ~ 8 1 5 ~ 7 8 0 ~ 4 4 9 , 4 8}$ \\
\hline consumer & 31283859162,54 & 37897327162,23 & 36046162271,55 \\
\hline real estates & 1463981011,30 & 1647989725,66 & 1705225222,04 \\
\hline other applications & 326413007,50 & 684646905,73 & 383503216,49 \\
\hline other & 1629106774,39 & 1839013551,75 & 1739230927,28 \\
\hline
\end{tabular}

Source - www.bnr.ro

Analyzing the situation for credits lent to the population it can be determined that individuals have been inclined especially towards consumer credits and have been less interested of those destined for purchasing real estates. Though consumer credits detain out of the total credits lent to the population over $90 \%$ in each year from the analyzed period, as for the credits for real estate purchases is situated below 5\%, consumer credits lent in RON to individuals have registered an increase of $15,22 \%$ for the analyzed period, while those destined for real estates registered an increase of $16,47 \%$.

Table no. 3 The evolution of credits lent in RON for the period of 2007-2009

$\%$

\begin{tabular}{|c|c|c|c|}
\hline RON & Dec 2007 & Dec 2008 & Dec 2009 \\
\hline Credits in $\mathrm{RON}$ & 100 & 100 & 100 \\
\hline economic agents & 48,08 & 48,92 & 49,17 \\
\hline population, of which: & 49,52 & 48,88 & 48,65 \\
\hline
\end{tabular}




\begin{tabular}{|l|r|r|r|}
\hline consumer & 93,18 & 92,57 & 92,86 \\
\hline real estates & 4,36 & 4,02 & 4,39 \\
\hline other applications & 0,97 & 1,67 & 0,99 \\
\hline other & 2,40 & 2,19 & 2,18 \\
\hline
\end{tabular}

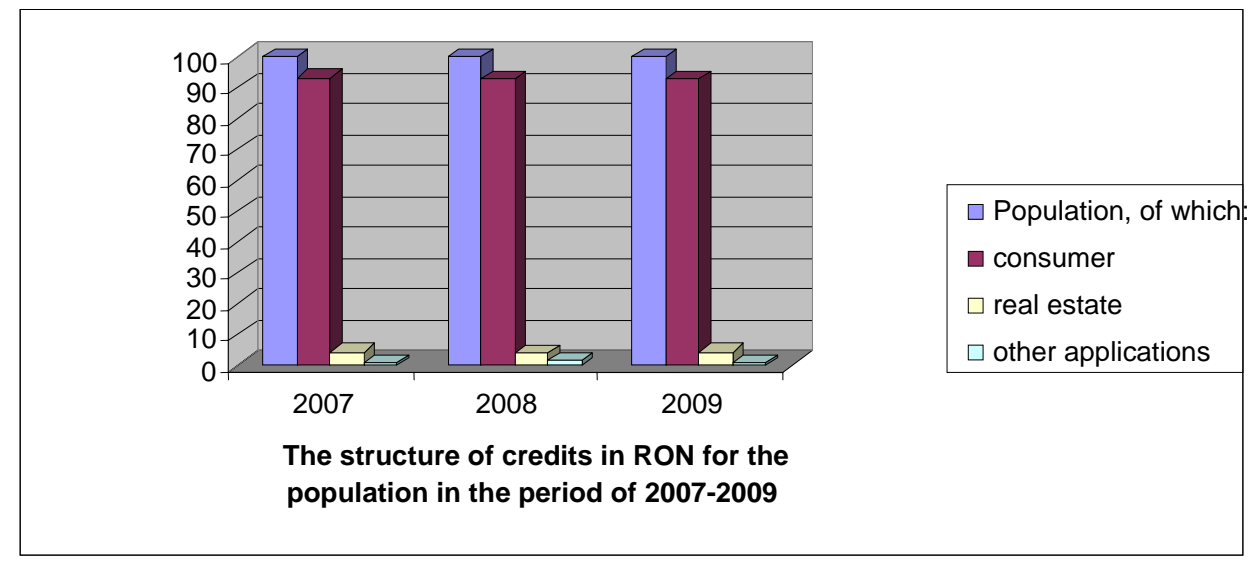

Graphic no. 2

Source - www.bnr.ro

Granted credits in currencies have registered bigger values as those in RON, which reflects the consumers' preference toward other monetary units over that of the national ones. Credits granted in RON have registered bigger values at the end of year 2008, and in 2009 although their value had a decreasing tendency; it was situated above the registered value at the end of year 2007. Credits in currencies have registered an increasing tendency for the analyzed period, thereby in 2009 they registered an increase of $49,06 \%$ in 2009 in regard to 2007 and an increase of 5,26\% in regard to 2008. It can be observed that the rate-of-rise was a lot bigger in 2008 in regard to 2007 , of $43,80 \%$, than in the second part of the analyzed period.

As for the default credits in other currencies it can be said that as ponderosity they have increased in every year analyzed. If in 2007 they detained a ponderosity of $0,40 \%$ of total credits in other currencies, in 2009 this ponderosity has increased to $2,86 \%$.

Table no. 4. The evolution of current credits and overdue debts in currency for the period of 2007-2009

\begin{tabular}{|l|r|r|r|}
\hline \multicolumn{1}{|c|}{ RON } & Dec 2007 & \multicolumn{1}{c|}{ Dec 2008 } & \multicolumn{1}{c|}{ Dec 2009 } \\
\hline Credits in currency & 81461466302,82 & 115360662075,02 & 121423852981,49 \\
\hline current & 81131240341,80 & 114372241380,10 & 117949550392,62 \\
\hline Overdue debts & 330225957,95 & 988420694,74 & 3474302588,66 \\
\hline Source - www.bnr ro
\end{tabular}

Regarding the evolution in the analyzed period, the increase is extremely high, therefore overdue debts in other currencies have increased from 330225957,95 in 2007, to 3474302 588,66 in 2009. The rate-of-rise for the overdue debts values has been bigger in 2009 in regard to 2008, compared to the previous period. 
Table no. 5 The evolution of current credits and overdue debts in currency for the period of 2007-2009 \%

\begin{tabular}{|c|c|c|c|}
\hline RON & Dec 2007 & Dec 2008 & Dec 2009 \\
\hline Credits in currency & 100 & 100 & 100 \\
\hline current & 99,59 & 99,14 & 97,13 \\
\hline Overdue debts & 0,40 & 0,85 & 2,86 \\
\hline
\end{tabular}

Credits granted in currency have registered an increase for the analyzed period not only for individuals, but also for legal entities. The rate-of-rise has been bigger in the first part of the period, therefore credits destined for legal entities have registered an increase of $32,73 \%$ in 2008 in regard to 2007, and an increase of 6,64\% in 2009 in regard to 2008. Regarding individuals the tendency has remained the same, thus in 2008 in regard to 2007 the growth has been of 53,64\%, and in 2009 in regard to 2008 the growth has been of 5,37\%.

Table no. 6 The evolution of credits in currency for the period of 2007-2009

\begin{tabular}{|l|r|r|r|}
\hline \multicolumn{1}{|c|}{ RON } & \multicolumn{1}{c|}{ Dec 2007 } & \multicolumn{1}{c|}{ Dec 2008 } & \multicolumn{1}{c|}{ Dec 2009 } \\
\hline Credits in currency & 81461466302,82 & 115360662075,02 & 121423852981,49 \\
\hline Economic agents & 40777915333,56 & 54127863274,08 & 57725183378,23 \\
\hline Population, of which: & 38126333332,95 & 58577508116,30 & 61725254654,47 \\
\hline consumer & 23955156808,80 & 35977804517,76 & 36977831260,92 \\
\hline real estate & 12782621978,92 & 19342714838,70 & 22622922261,30 \\
\hline other applications & 1191104854,94 & 2892165660,09 & 1724791352,91 \\
\hline
\end{tabular}

Source - www.bnr.ro

Concerning the ponderosity for different types of credits granted in currency for every year in part, consumer credits detain the highest ponderosity, being followed closely by credits for real estate purchases. Compared to the credits granted in RON, the population opted mostly toward the credits in currency destined for the real estate purchases.

Table no. 7 The evolution of credits in currency for the period of 2007-2009

\begin{tabular}{|l|r|r|r|}
\multicolumn{1}{|c|}{ RON } & Dec 2007 & \multicolumn{2}{c|}{ Dec 2008 } \\
\hline $\begin{array}{l}\text { Credits in currency } \\
\text { population, of which: }\end{array}$ & 100 & 100 & Dec 2009 \\
\hline consumer & 62,83 & 61,42 & 59,90 \\
\hline real estate & 33,52 & 33,02 & 36,65 \\
\hline other applications & 3,13 & 4,93 & 2,80 \\
\hline
\end{tabular}

For the analyzed period the value of credits in currency granted for real estate purchases have registered an increase for the entire analyzed period.

The financial behavior of the banking services' consumers regarding the contracting of credits for the analyzed period has been influenced, for the most part, by external factors of the consumer, factors that have originated from the environment in which he/she lives and proceeds with his/hers daily activities. Thus the economic environment of the country, being influenced by the international environment has had a powerful impact over the consumers. 


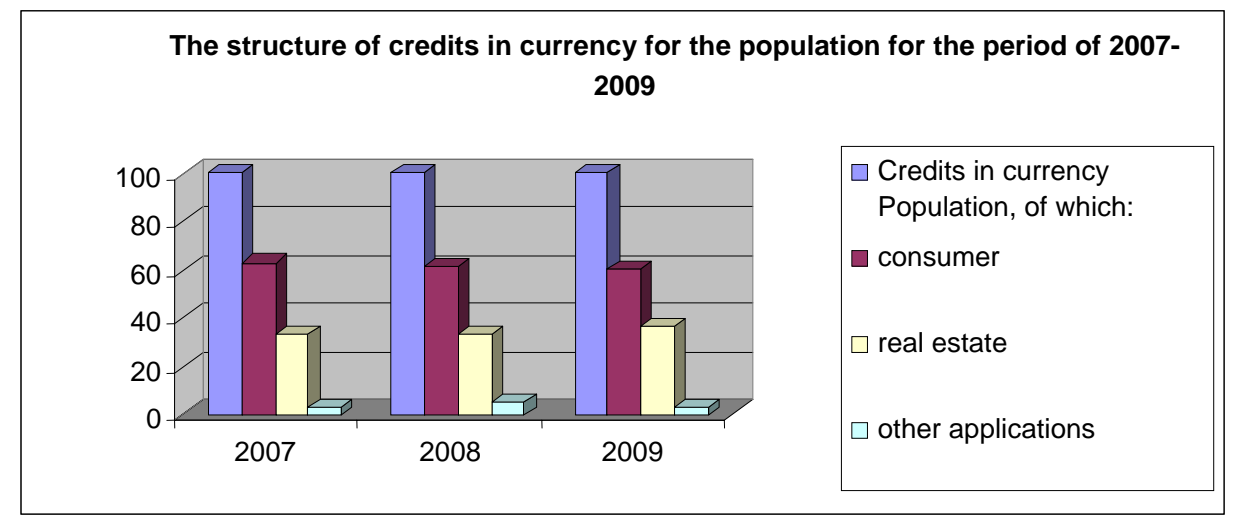

Graphic no. 3

Source - www.bnr.ro

The consumer's behavior for banking services is influenced by a series of factors such as cultural factors, social factors, and personal factors, psychological and economical factors.

The culture represents the assembly of standards, beliefs and values, of the collective representations of the majority of subjects from a group. The cultural factors can be associated to language, morals, ethics, traditions, personal values, beliefs. ${ }^{3}$ These factors influence the individuals still from their childhood, through family and through the way it develops. Therefore it can be appreciated that in fact that culture is deeply ingrained in the human behavior. Its modification requires a longer time, a reason for which, from marketing's point of view, it is beneficial to be working considering it how it is, without trying to modify it.

Social factors have influence over the consumers' behavior within the buying and consuming process, reference groups of the client, social classes. The most powerful factor of influence is family. The role of the family is defined as being various throughout the world, and the marketing operators must determine the characteristics of the particular markets. ${ }^{4}$

The attitude for saving has to be cultivated from childhood, hence in the family. Banks approach the youth through specific offers, which can attract and make them faithful clients. Thus they can offer a series of banking products and services specific for different segments of consumers. From marketing's point of view, the notion of social classes leads to a segmentation of the market, which offers an operational potential. Social classes are determined in general by the origin, family conditions, occupation, and source of income, home and type of home, education and educational level. ${ }^{5}$ The analysis of the utilization of banking products and services can be made on segments of consumers dependent on the occupation, education, life style, etc.

The consumer's behavior is also influenced by personal factors such as: age, life-cycle stage, lifestyle, personality, and auto-concept. On different ages and stages of the life-cycle, people have different needs. Over the lifetime of an individual, his/her needs are continuously modified. A young person is interested in style, traveling, entertainment; he/she

\footnotetext{
${ }^{3}$ Olteanu Laura,Serviciile în România şi comportamentul consumatorului de servicii bancare-persoană fizică, 2007, Risoprint, Cluj Napoca, pg. 102

${ }^{4}$ Dubois Pierre Louis, Jolibert Alain, Marketing. Teorie şi prectică,vol. I, 1989, ed. Economică, Imprimeria Ardealul Cluj, Cluj Napoca,pg.97

${ }^{5}$ Dumitru D. Lazar, Marketing pentru studenți, 1998, Ed. Continental, Alba Iulia, pg. 50
} 
isn't inclined to saving money; an elder person, that doesn't spend much on clothes, prefers to deposit its money for safekeeping.

Age. Age-groups represent, for the marketing operators, distinct life-segments that are accosted with different policies and strategies. ${ }^{6}$

Another factor of influence of the consumer's behavior is its occupation. Through its occupation the individual integrates itself in a group, that being a primary or secondary group; concurrently it belongs to a social class of which characteristics imprint particular features into their behavior.

Occupation. In terms of occupation, the individual has or hasn't got free time. Consumers are strongly influenced by their rate of incomes, in the buying process, that they dispose of. The existence of the requisition is conditioned by the existence of needs, buying capacity and the possibility of choice. The absence of one of these elements deters the manifestation of proper requisition. $^{7}$

Practice has demonstrated that the rate of income is inter-conditioned with the occupation, the individual's free time, and with the lifestyle.

A need satisfied, generates new needs. The increase of the rate of income determines the satisfaction of a new need, unsatisfied due to the absence of certain financial availabilities. Moreover the increase of incomes determines a change of the lifestyle embodied by different solicitations and different consumes. We can determine the consumer's change in orientation from quantity to quality. ${ }^{8}$

The attitude towards savings alters; if, at small sums the detainer isn't tempted to deposit at banks, in the situation of the increase of financial availabilities it will be tempted to make savings through deposits in RON and other currencies and also to purchase other banking products. ${ }^{9}$

Within the factors that have influence over the consumer's behavior there also can be distinguished psychological factors. Those are perception, motivation, learning, attitude, appreciation and opinion ${ }^{10}$.

The multitude of factors that influence the consumer's behavior must be taken in account within an expertise/analysis.

In case of a crisis-period the consumers react in different ways. The attitude, the experience, the education, the rate of income, social classes, the perception, the attitude toward risks conditions the consumer's behavior referring to credits that can be contracted.

\section{Bibliography}

1. Dardac Nicolae, Basno Cezar,(1996), Operațiuni bancare. Operațiuni şi tehnici de plată, Ed. Didactică şi pedagogică, Bucureşti

2. Dubois Pierre Louis, Jolibert Alain,(1989,) Marketing. Teorie şi prectică, vol. I, Ed. Economică, Imprimeria Ardealul Cluj, Cluj Napoca

3. Dumitru D. Lazar,( 1998), Marketing pentru studenți, Ed. Continental, Alba Iulia

4. Ionescu Lucian (coordonator),(1996), Fundamentele profesiunii bancare. Băncile şi operațiunile bancare, Ed. Economică, Bucureşti

5. Olteanu Laura, Fazakas Jozsef,(2005) Interdependența dintre comportamentul consumatorului şi valoare de întrebuințtare a mărfii, Presa Universitară Clujană, Cluj Napoca

6 Olteanu Laura, Fazakas Jozsef, Interdependența dintre comportamentul consumatorului şi valoare de întrebuințare a mărfii, 2005, Presa Universitară Clujană, Cluj Napoca, pg.35

${ }^{7}$ Olteanu Laura, Bazele marketingului, 2009, Risoprint, Cluj Napoca, pg. 112

${ }^{8}$ Olteanu Laura,Serviciile în România şi comportamentul consumatorului de servicii bancare-persoană fizică, 2007, Risoprint, Cluj Napoca, pg. 111

${ }^{9}$ Olteanu Laura, Fazakas Jozsef, Interdependența dintre comportamentul consumatorului şi valoare de întrebuințare a mărfii, 2005, Presa Universitară Clujană, Cluj Napoca, pg.38

${ }^{10}$ Olteanu Laura, Bazele marketingului, 2009, Risoprint, Cluj Napoca, pg. 113 
6. Olteanu Laura,(2009), Bazele marketingului, Risoprint, Cluj Napoca

7. Olteanu Laura,(2007), Serviciile în România şi comportamentul consumatorului de servicii bancare-persoană fizică, Risoprint, Cluj Napoca

8. www.bnr.ro 